\title{
Pastures and Forage Crops for Horses ${ }^{1}$
}

\author{
M. Wallau, E. L. Johnson, J. Vendramini, C. Wickens, and C. Bainum²
}

Florida's unique climatic characteristics allow for forage production most of the year with a large variety of possible forage choices. Independent of the size of the operation and number of horses, good forage planning can help reduce feeding costs, environmental impacts, and nutritional disorders caused by high-concentrate feeding. With the exception of high-performance animals, horses can meet most of their nutritional needs from pasture. However, achieving this requires careful planning and implementation of a forage production and utilization program. Horses are hindgut fermenters and have an increased passage rate in the intestine, allowing them to process a larger amount of forage. This is an advantage for horses at maintenance, broodmares in early gestation, and retired horses that can derive the majority of their nutrition from pasture.

Pastures for horses can be grown throughout the state. The choice of forage species varies from site to site due to variations in soil and climatic conditions. The role of improved pastures in supplying forage varies depending on several aspects, including available area, general pasture management, facilities and equipment, and personal preference of the operator. The factors that must be considered in improved pasture production are site characteristics, production goals, forage varieties, liming and fertilization, and grazing management. High-quality pasture and/or hay (e.g., well-fertilized bermudagrass, rhizoma peanut, cool-season forages) can provide a balanced ration of energy, protein, minerals, and vitamins. However, horses grazing average or low-quality pasture (bahiagrass) may require protein and mineral supplementation.

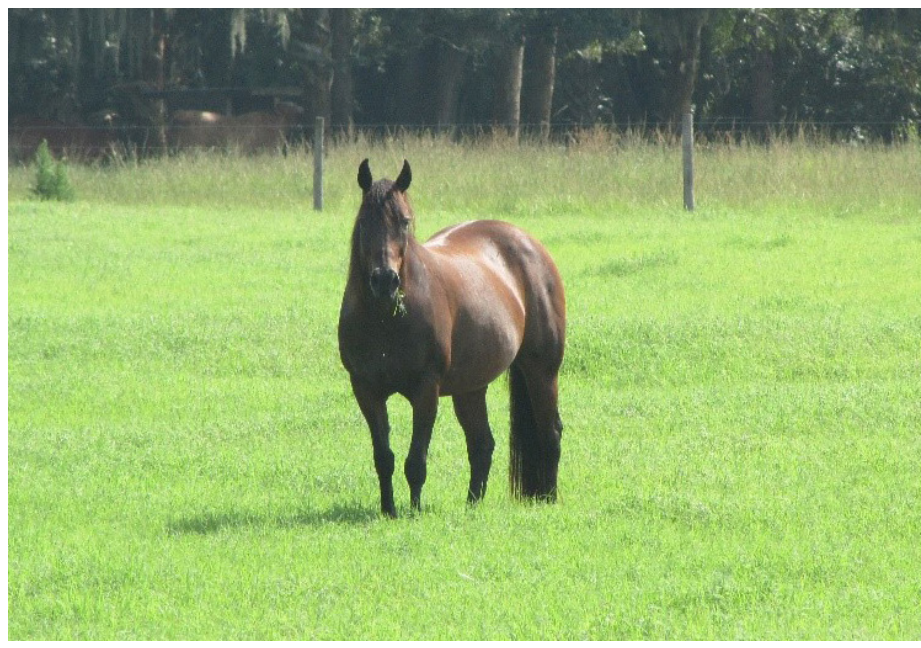

Figure 1. Horse grazing bermudagrass.

Credits: Marcelo Wallau, UF/IFAS

\section{Intake and Nutrient Requirements}

Horses that do not receive supplemental feed will consume about $1.5-2.5 \%$ of their body weight as forage per day on a dry matter basis. Thus, a horse weighing 1,000 lb would require 15-25 lb of dry matter per day, which represents around 18-29 lb of hay or 50-100 lb of fresh

1. This document is SS-AGR-65, one of a series of the Agronomy Department, UF/IFAS Extension. Originally written by C. G. Chambliss and E. L. Johnson in May 1997. Revised January 2019. This publication is also a part of the Florida Forage Handbook, an electronic publication of the Agronomy Department. Visit the EDIS website at https://edis.ifas.ufl.edu for the currently supported version of this publication.

2. M. Wallau, assistant professor, forage Extension specialist, Agronomy Department; E. L. Johnson, associate professor, Department of Animal Sciences; J. Vendramini, associate professor, Agronomy Department, UF/IFAS Range Cattle Research and Education Center; C. Wickens, assistant professor, Department of Animal Sciences; and C. Bainum, Extension agent, UF/IFAS Extension Marion County; UF/IFAS Extension, Gainesville, FL 32611.

The use of trade names in this publication is solely for the purpose of providing specific information. UF/IFAS does not guarantee or warranty the products named, and references to them in this publication do not signify our approval to the exclusion of other products of suitable composition.

The Institute of Food and Agricultural Sciences (IFAS) is an Equal Opportunity Institution authorized to provide research, educational information and other services only to individuals and institutions that function with non-discrimination with respect to race, creed, color, religion, age, disability, sex, sexual orientation, marital status, national origin, political opinions or affiliations. For more information on obtaining other UF/IFAS Extension publications, contact your county's UF/IFAS Extension office. 
forage, depending on the dry matter content of the forage. Horses need to eat sufficient forage to obtain nutrients and to ensure the fiber maintains normal gastrointestinal function. The fiber concentration of a suitable horse hay should contain $30-40 \%$ acid detergent fiber (ADF), which is a percentage of the forage that is least digestible by the animal, such as cellulose and lignin. The higher the ADF content, the lower the energy level. Approximately 50-70\% of the fiber should be neutral detergent fiber (NDF), which contains the same components as ADF plus hemicellulose in order to provide normal gastrointestinal function. Table 1 shows general daily nutrient requirements for different horse classes and the target nutrient concentration of forages, considering an intake of $2 \%$ body weight for a 1,000-lb horse (or $500 \mathrm{lb}$ for the growing class). For more information on horse nutrition, refer to EDIS document AN235, Basic Nutritional Guidelines for Equine Management (http:// edis.ifas.ufl.edu/an235), and EDIS document AN236, How to Feed a Horse: Understanding Basic Principles of Horse Nutrition (http://edis.ifas.ufl.edu/an236). The National Research Council (NRC) provides a useful website (http:// nrc88.nas.edu/nrh) for determining nutrient requirements and balancing diets for horses. Table 2 shows a few general nutrient concentrations for common Florida summer perennial pastures.

\section{Planning your Pastures}

There are many usable forage choices for horses in Florida. The "best forage" depends on many factors, including site characteristics, use objective, and management level. There are a few important aspects that should be considered when planning your forage program:

- What species can be grown in the chosen area, depending on adaptation to soils and climate

- Growing season and peak of demand (both in terms of quantity and nutritive value)

- The way the forage will be used (grazed or hay; as a turnout paddock or continuous stocking; as main fiber source or supplemental, high-nutritive value forage)

- Class of horses (breeding stallion, broodmare, growing horse, or horse in training)

- Level of management required for optimum pasture production versus the skill of the manager

Soil characteristics and climate are important factors in selection. Soil drainage is particularly important because certain forages, such as perennial peanut, bermudagrass, and small grains, do not tolerate poorly drained soils. Bahiagrass, ryegrass, and white clover, on the other hand, are adapted to a wide range of soil drainage types and can tolerate wetter areas. Higher-quality forages usually require more management and fertilization (e.g., bermudagrass and small grains), while those with the primary purpose of maintaining cover often require less intensive management (e.g., bahiagrass). It is possible, however, to mix and match forage species and management practices (e.g., fertilization, mowing, and haying) to expand the growing season. For example, cool-season forages can be overseeded into bahiagrass to extend the grazing season, significantly reducing feed costs. While some species require a prepared seedbed to be established, others can be overseeded or drilled into existing sod. When equipment is a major limitation, broadcasting can be an alternative (e.g., ryegrass for winter grazing).

\section{Forage Species}

Detailed discussion of production and management of forage crops mentioned below is available in the Florida Forage Handbook: Table of Contents (http://edis.ifas.ufl.edu/ ag170).

\section{Warm-Season Perennial Grasses}

Bahiagrass is the most cultivated summer perennial forage in Florida. Once established, it can withstand heavier grazing pressure than other commonly used pasture grasses, and it generally requires less fertilization to maintain productivity. The peak of production is during the summer, although higher temperatures during the winter in south Florida allow minimal growth. Some cultivars such as UF-Riata are less sensitive to photoperiod and can grow into the fall months. However, nutritive value is generally moderate, especially without fertilization, and drops significantly with maturity (i.e., stockpiled pastures). When mature, all of the bahiagrasses are fibrous and low in feeding value, but the quality of the pastures can be improved by overseeding alyce clover or intercropping rhizoma perennial peanut.

Recommended cultivars include Pensacola, Argentine, Tifton-9, and UF-Riata. Pensacola is the most widely grown cultivar of bahiagrass. It is persistent under close grazing and low input management. Tifton-9 produces more top growth than other cultivars but may be less tolerant of overgrazing. Both Tifton-9 and Pensacola are more frostresistant than Argentine or Paraguay 22. Argentine and Paraguay 22 have wider leaves than Pensacola or Tifton-9. Argentine can develop ergot fungus on the seed heads. This can cause ergot alkaloid toxicity, which can lead to abortion in pregnant mares. 
Bermudagrass produces rapidly from vegetative plantings and is vigorous and highly productive. It is more responsive to fertilization but has higher nutrient requirements for growth than bahiagrass. It makes an excellent hay crop when harvested frequently (every $4-5$ weeks). Bermudagrasses require careful management and can be severely damaged by continuous overgrazing. They should not be planted on sites that flood or have very poor drainage.

Recommended cultivars include Coastal, which is finestemmed and popular among horse owners, Suwannee, Tifton-44, Jiggs, Florakirk, and Tifton-85. Tifton-85 is vigorous and high yielding, and it can have superior digestibility. Florakirk is recommended only for hay production. Alicia, an older but popular variety, is less digestible and less productive than Tifton-85. All of the improved hybrid bermudagrasses must be established from vegetative planting material. Common bermudagrass can be established by planting seed, but the common types are usually low quality, more susceptible to leaf diseases and stem maggot, and much less productive.

The stargrasses are related to the bermudagrasses and are adapted only to south central and south Florida. Three cultivars-Ona, Florona, and Florico-are recommended. These grasses are very productive when grown under high fertility. It should be noted that the potential for prussic acid poisoning exists with stargrasses, but is seldom a problem. The stargrasses make excellent hay, but many horse owners prefer the finer-stemmed bermudagrass hays.

Limpograss is adapted to poorly drained soils. It is highly productive during the summer and fall and frequently used as stockpiled forage for cattle during the winter. Despite the low crude protein, it has high digestibility and declines slower with maturity than bermudagrass and bahiagrass. Recommended varieties are Floralta, Gibtuck, and Kenhy. There is no horse performance information currently available for this forage.

Warm-season perennial grasses that are not recommended due to their low production or quality, but may invade a horse pasture, are common bermudagrass, centipedegrass, carpetgrass, and torpedograss. Common bermudagrass, if highly fertilized, can be quite productive. It will often provide ground cover in high-traffic areas when other grasses will not. Centipedegrass is adapted to areas with good drainage, and carpetgrass and torpedograss are adapted to moist flatwoods sites but have low productivity. These grasses tolerate close grazing and may invade more productive grasses when pastures are overstocked.

\section{Summer Annual Grasses}

Pearl millet is useful to complement perennial summer grasses and is higher in nutritive value than most perennial grasses. It is highly productive under adequate fertility, but it will not tolerate flooding. Growth can be so rapid that grazing management is difficult.

Crabgrass, which is often viewed as a weed invading bermudagrass fields, can be a highly nutritious and palatable forage. Horses generally prefer it to perennial pastures such as bahiagrass. Crabgrass is less productive and highly dependent on rainfall and fertilization. It can be used as a good complementary forage.

Sorghum, sudangrass, and sorghum-sudangrass hybrids are NOT recommended for horse pastures due to prussic acid poisoning, which may cause abortion in mares in early pregnancy, cystitis, and problems with the urinary tract.

\section{Summer Legumes}

Rhizoma peanut is an excellent forage for horses because of its high feed value. It is often used as a substitute for alfalfa, especially as hay. Rhizoma peanut is a persistent, perennial, rhizomatous legume adapted to well-drained soils over the entire state. Rhizoma peanut may be grazed or cut for hay or silage. Florigraze and Ecoturf are the recommended cultivars for grazing and hay, although other varieties such as UF-Tito, Arblick, and UF-Peace are more "hay types." Establishing is onerous and slow, often requiring two seasons to develop complete ground cover. However, once the plant is established, it is very persistent and productive. It is propagated via rhizomes (sprigs) and best established in a clean seedbed. Alternatively, it can be strip-planted into existing bahiagrass pastures to reduce establishment costs. More information on establishment can be found at https://edis.ifas.ufl.edu/ag358 and http:// edis.ifas.ufl.edu/ag421.

Alyce clover is a high-quality annual legume that is readily accepted by horses. Currently available alyce clover types are susceptible to attack by root-knot nematodes. It should not be planted on soils subject to long periods of flooding. It is an excellent hay crop and is frequently planted following watermelons to take advantage of the residual fertility.

\section{Winter Annual Grasses}

Cool-season annual grasses are an excellent choice for extending grazing from the late fall through the early summer. They have a special place in central and north Florida pastures because of the large influx of horses during winter and spring. 
Small grains, including oat, rye, and triticale, all furnish good grazing during December, January, February, and March if planted between October and November. Those species are more suited to well-drained sites, require a good level of fertilization to be productive, and can benefit from irrigation, especially for early establishment. The cost of land preparation, planting, and fertilization is relatively high but easily offset by the reduction of hay fed. Those forages can also be used to produce high-quality hay.

Annual ryegrass is another great option for winter forage. It is highly productive and has a longer growing season than small grains. It generally starts producing by late January and can be grazed until April or May, depending on the conditions. Certain improved varieties, such as Earlyploid or Jumbo, are faster growing than Gulf or Marshal, and can be grazed earlier in the season. It has a high moisture requirement, can be used in wet areas, and is very responsive to fertilization. Pairing small grains and ryegrass is a great alternative to extend the grazing season, because the small grains start producing earlier than ryegrass. A good option for horse farms is oat, ryegrass, and crimson or red clover. The bottleneck for winter annual grasses is the temperature and moisture during establishment. The fall drought in October and November can delay planting. The high temperatures can increase competition from existing sod (in the case of overseeding or drilling into existing sod) and also increase the risk of diseases such as rust. Therefore, it is important to choose varieties that are rust-resistant. Before deciding on which cultivar to use, refer to the yearly Cool-Season Forage Variety Recommendations for Florida (https://edis.ifas.ufl.edu/aa266).

\section{Winter Legumes}

Clovers make excellent winter forages for horses, especially when mixed with the small grains or ryegrass for overseeding bermudagrass and bahiagrass sods. A mixture of clover is usually recommended. White clover is better adapted to wetter sites, while red, crimson, and arrowleaf clover are better adapted to well-drained locations. For more information, see EDIS document SS-AGR-49, Winter Forage Legume Guide (http://edis.ifas.ufl.edu/ds127).

Alfalfa is a forage of choice for many horse owners. It is typically fed to horses as hay or in a mixture with a grass such as timothy in temperate climates. Alfalfa production in Florida is very limited; most of the hay is shipped in from the Midwest or the West. In recent years, alfalfa has been grown with some success if planted on moderately to well-drained sites of north Florida, with stands lasting only two years. New research mixing alfalfa and bermudagrass has shown some promising results in Georgia. Alfalfa requires intensive management, including high levels of fertility and favorable moisture conditions. Excellent hay can be made from this plant, but high humidity in Florida makes drying difficult.

\section{Pasture Management}

Through good management and planning, it is possible to ensure that pastures are the main source of feed for horses, and less supplemental feed is required during the year. A combination of forage species will more adequately meet the forage needs of horses on pastures than a single forage species will. Typically, a perennial forage species such as bahiagrass, bermudagrass, or stargrass (south Florida) may serve as the base pasture to supply most of the forage needs on pasture during the summer. Depending on the needs of the operation during the summer (i.e., more yield or higher quality), summer annual grasses (e.g., pearl millet) and legumes (e.g., alyce clover) may be grown. For boarding facilities where most of the demand is during the winter, cool-season forages such as oat, ryegrass, and clovers may be used to meet forage needs.

\section{Establishing Pastures}

Establishment is the most important and expensive phase of the pasture. Before establishing any pasture, it is important to 1) choose a forage species adapted to your soil and climate conditions; 2 ) choose the forage species that is suitable to your management practices and animal needs; and 3) take soil samples and start preparing the area in advance.

Successful establishment and long-term productivity of a pasture will depend on the preparation of the planting site and choice of species. Before land preparation begins, soil samples should be taken for analysis and determination of fertilization and liming requirements. Site preparation determines the overall success of pasture establishment: a clean, tilled, weed-free seedbed is essential for all perennial crops. Start land clearing and preparation early to allow the lime time to stabilize the $\mathrm{pH}$ (it takes three to six months to be effective) and improve weed control. Proper weed control can ensure a more productive and persistent pasture. Furthermore, it is easier and cheaper to control weeds prior to establishing the pasture than it is to remediate later. A broad-spectrum herbicide (e.g., glyphosate) can be used for clearing the area, but depending on existing pasture crop and weed pressure, several applications may be required. If sod or weeds are persistent, it is possible to use an intermediate annual crop for one season in order 
to reduce competition before establishing the perennial pasture. Frequent tilling exposes the vegetation to the heat of the sun and facilitates desiccation.

Forage crops may be established by seed or vegetative materials. All those planted vegetatively require thorough tillage, while seeded crops can be drilled or broadcasted into sod or prepared seedbed. Table 3 provides information on the type of planting material needed, recommended planting rate, planting dates, and time-to-graze for each forage crop. While perennial crops may require or benefit from tillage, annual crops can be drilled or broadcasted (e.g., ryegrass and clovers) into existing sod. This practice is common for intercropping cool-season forages in a perennial summer pasture without affecting the productivity of the perennial crop. The most common practice is to drill oat, ryegrass, and clovers into bahiagrass pastures. Before overseeding, the sod should be heavily grazed, mowed, or burned to remove the top growth. A small dose of herbicide can also be used to suppress bahiagrass growth. The small grains (rye, wheat, oat, and triticale) may perform poorly when overseeded on a bahiagrass sod unless the sod has been disturbed by disking or chopping. Bahiagrass should be cultivated (disked) to obtain 30-50\% disturbance in order to provide good seed-to-soil contact and reduce the competition from the bahiagrass. For more information on pasture establishment, see EDIS document SS-AGR-161, Forage Planting and Establishment Methods on Prepared Seedbed (http://edis.ifas.ufl.edu/ag107).

\section{Maintaining Pastures}

Routine soil testing will aid the development of an efficient liming and fertilization program, which is necessary to maintain productive pastures. Soil $\mathrm{pH}$ will change over time depending on soil type and type of fertilizer used. Lime or dolomitic lime may be required to increase soil $\mathrm{pH}$ to between 5.5 and 6.5 , which is the range in which nutrients are most available to the plant. Nitrogen, phosphorus, and potassium are the three major nutrients required by the growing grass, with $\mathrm{N}$ generally being the most limiting for production and $\mathrm{K}$ the most limiting for persistence. Where there is a good stand of a legume in the pasture, an inorganic nitrogen application may not be required because legumes are able to utilize atmospheric nitrogen (via biological nitrogen fixation) and make it available to the companion grass in the long run (nitrogen transfer). Furthermore, inorganic nitrogen fertilizers may adversely affect legume stand persistence. Still, starter nitrogen may be required due to the low organic matter of most soils in Florida. Under grazing, nutrients are recycled back to the pasture through manure and urine; thus, additional nutrient application with fertilizer may be less than what is needed for a hay crop where the forage is harvested and removed from the land. For more information on liming and fertilizing pasture, see EDIS document SS-AGR-176, Fertilizing and Liming Forage Crops (http://edis.ifas.ufl.edu/ ag179).

Proper land preparation during pasture establishment and grazing management will go a long way in minimizing weed infestation in the pastures. Adequate weed control can be accomplished through a combination of grazing management, herbicide applications, and mowing. When there is bare space in the pasture (e.g., through overgrazing), there are more chances for weeds to establish. Mowing alone can often slow but not reduce the weed problem. Nevertheless, it may be required to reduce the size of weeds for a more effective herbicide control. Herbicides are the most common and generally most affordable and effective form of weed control. Before selecting an herbicide, you must 1) identify the target weed, 2) determine the stage of the weed (it is generally better to control when weeds are immature), and 3) know your main crop and the stage at which it is growing. See EDIS document SS-AGR-08, Weed Management in Pastures and Rangeland-2018 (http://edis. ifas.ufl.edu/wg006), for more information on herbicide recommendations for pastures.

As indicated above, significant amounts of nutrients are recycled through the manure of grazing animals. In small pastures where there is a concentration of horses, manure can be spread with a light drag. Dragging, however, has limited effect and does not eliminate the need for fertilizer. If manure is being applied to pasture as a soil amendment, it should be composted first to eliminate pathogens, weed seeds, and parasites. Composting will also stabilize the material before it is spread on the pasture. Otherwise, manure can be detrimental to the pasture, acting as a sink, instead of a source, of nitrogen. Mowing areas where horses do not graze and dragging pastures to spread manure piles can improve quality and utilization of the pasture, but efficacy depends on pasture size and utilization. Pests of pastures are not usually severe enough to justify insecticide application, but occasional outbreaks can be controlled with pesticides. Before using pesticides, carefully read the labels and follow directions for use. Certain products require a withdrawal period of the horses from the pasture.

Grazing management is a valuable tool for maintaining pastures. The most important aspects of grazing management are adjusting the herbage allowance (or always being sure we are offering two to three times more forage than the animals can eat) and a minimum stubble height to avoid 
overgrazing. It is important to calculate your forage budget and determine the amount of forage that can be produced in a certain period of time as well as the amount of forage that is needed. Secondly, pastures can be continuously or rotationally stocked. In continuous stocking, horses graze the same pasture for the entire grazing season or year. In rotational grazing, the pasture is divided into paddocks that are grazed alternately. Rotational grazing is a valuable management practice to maintain and efficiently utilize productive pastures, but it will not solve the problem of overstocking. Available pasture may be subdivided into smaller paddocks, and horses are rotated normally in periods of three to 21 days. Paddock size and rest period are variable and dependent on many factors, including type of pasture, stocking rate, season, and grazing intensity. If the grazing intensity is high (i.e., lower stubble height or residual mass), it is necessary to allow a longer period of regrowth. This method allows better control of pasture regrowth, helps avoid overutilized or underutilized spots, and permits better organization of pasture production and utilization. Dividing pastures also gives the manager some flexibility with pasture management. During periods of excessive forage growth in the summer, some paddocks may be closed and used for stockpiling forage or for making hay or silage for use during periods of limited forage availability. This can further reduce the need for supplemental feeds. Fencing is essential in rotational grazing and pasture management. Paddock subdivision can be done inexpensively using electric fence.

\section{Land Area Required (Stocking Rate)}

The issue of stocking rate raises a common but often difficult question: how many acres per horse? The stocking rate will vary with the forage species grown and its productivity, the size and age of the horse, the amount of grain and other supplements fed, and grazing management. It is better to address this question while considering the herbage allowance. As a rule of thumb, we need to offer two to three times more forage than the animal can consume to ensure the persistence of the pasture and adequate availability of forage. For that, we need to calculate our pasture productivity (both quantity and quality) and our animal demand. In general terms, considering an average bahiagrass pasture, one mature horse weighing 1,100 pounds may require $2-2.5$ acres of pasture. In more productive sites, such as wellfertilized bermudagrass pastures or winter forages, 1-1.5 acres may be adequate for a mature horse. The bottom line is to always assure sufficient forage for the animals, and never overgraze. Very short forage limits the animal's capacity to graze as well as the plant's capacity to regrow.
Pasture productivity depends heavily on the forage species and management practices, and varies throughout the year. In the summer, production and nutritive value of warm-season perennial grasses (e.g., bahiagrass and bermudagrass) may be adequate to meet the requirements of a mature horse, but are likely to be limiting for growing or working/athlete stock due to lower protein and energy. In the winter, bahiagrass and bermudagrass go dormant, and supplemental feed becomes a necessity to meet the horse's nutritional requirements. Alternatively, cool-season forages (e.g., ryegrass, oat, and clovers) can be used to increase productivity and nutritive value of forage during the winter. As previously mentioned, rotational grazing can be an important tool for pasture management, but it will not solve overstocking problems.

Many horse owners have very limited pasture area and rely on supplemental feed (concentrate or hay) to meet nutritional demands. Still, proper pasture management can help reduce feeding costs, ensure longevity of the pasture, and reduce environmental impacts by facilitating active growth of the pasture. Animals can be housed in a sacrifice area (a drylot or designated area of the property where horses can be temporarily housed and provided with supplemental feed to allow pastures to rest or recover during unfavorable conditions) to be fed and maintained for a portion of the day, then turned out periodically into the pasture to graze. This type of grazing management aims to efficiently utilize the pasture and avoid overgrazing that may lead to the development of bare spots. In general, when there is more than one horse per acre, the pasture primarily functions as an exercise area. Its role as a source of feed becomes secondary. Avoid placing too many horses on too few acres for prolonged periods of time. This practice results in destruction of the pasture, encroachment of weeds, and increased costs associated with supplemental feeding.

\section{Hay}

For horses primarily on pasture, hay is supplementary. It has to compensate for pasture deficiencies. When hay becomes the major feed component, you should review the forage plan and see what is limiting pasture production. For stalled horses, hay is a very important component of the diet and is the primary source of fiber needed for normal gastrointestinal function. The choice of hay has to take into account nutritional requirements, which differ for each horse class, and all other dietary components (i.e., pasture, concentrate [feed], minerals, etc.). The only way to assure hay quality is through testing. Visual and olfactory cues can help you determine if the hay is free of weeds and mold, but these cues will not give much more information. Quality 
horse hay should be mold- and dust-free and should not contain weeds and poisonous plants. Good horse hay contains about $12-20 \%$ crude protein, with grass hays (such as Coastal and Jiggs) at the lower end of the range and legume (such as alfalfa and peanut) and annual forage hays at the upper end. Low-quality grass hay may contain $6 \%$ crude protein or less, and may be used for supplementing fiber to horses with access to lush pastures. A forage analysis that indicates moisture content, crude protein, acid detergent fiber (ADF) and/or neutral detergent fiber (NDF), calcium, and phosphorus provides objective criteria for judging hay quality. A forage analysis is also useful for ration formulation and supplemental feeding decisions. Contact your local UF/IFAS Extension office (http://sfyl. ifas.ufl.edu/find-your-local-office/) for assistance with hay sampling and analysis.

Production of quality hay involves a combination of proper management practices, including fertilization and cutting frequency. In Florida, climatic conditions restrict haymaking mostly to the spring and fall when there is adequate soil moisture to permit forage growth, and the weather favors rapid drying of the cut herbage. Hay fields can also be grazed during the summer months when excessive rainfall usually precludes haymaking. Production of hay from horse pastures may be an alternative for underutilized pastures, but it requires specific fertilization and cutting management for success. The decision on when to cut is extremely important for the quality of the hay: there is always a compromise between quantity and quality, and the longer the interval between cuttings, the lower the quality of the hay. The bermudagrasses (Coastal, Florakirk, Tifton 85, and Jiggs) and stargrasses (Florona) are generally of higher quality than bahiagrass, but they also require more fertilization to sustain high production and quality. Perennial peanut hay is another great alternative to local hay and is similar to alfalfa in quality.

\section{References}

Ball, D. M., C. S. Hoveland, and G. D. Lacefield. 2002. Southern Forages. Norcross, GA: Potash \& Phosphate Institute.

NRC. 2007. Nutrient Requirements of Horses. $6^{\text {th }}$ edition. Washington, D.C.: National Academies Press. 
Table 1. Daily digestible energy (DE) and target crude protein (CP) concentration values of forages for different classes of horses. Adapted from NRC (2007).

\begin{tabular}{|c|c|c|c|c|}
\hline \multirow[t]{2}{*}{ Animal Class } & \multicolumn{2}{|c|}{ Daily Requirements } & \multicolumn{2}{|c|}{ Target Values of Forage* } \\
\hline & DE (Mcal/day) & CP (lb/day) & DE (Mcal/lb) & CP (\%) \\
\hline Maintenance & 17 & 1.4 & 0.85 & 7 \\
\hline Growing & $15-19$ & $1.5-1.7$ & $1.5-1.9$ & $15-17$ \\
\hline Gestation & $17-21$ & $1.4-2.0$ & $0.85-1.05$ & $7-10$ \\
\hline Lactation & 32 & 3.4 & 1.6 & 17 \\
\hline Working & $23-27$ & $1.5-1.9$ & $1.15-1.35$ & $7.5-9.5$ \\
\hline
\end{tabular}

Table 2. Concentration of crude protein (CP), neutral detergent fiber (NDF), acid detergent fiber (ADF), total digestible nutrients (TDN), and digestible energy (DE) on common Florida summer perennial pastures. Adapted from Ball, Hoveland, and Lacefield (2002).

\begin{tabular}{|c|c|c|c|c|c|}
\hline \multirow[t]{2}{*}{ Forage Species } & $\mathbf{C P}$ & NDF & ADF & TDN & \multirow{2}{*}{$\begin{array}{c}\text { DE } \\
\text { Mcal/lb }\end{array}$} \\
\hline & \multicolumn{4}{|c|}{$\%$} & \\
\hline Coastal Bermudagrass & $10-14$ & 50 & 29 & $52-58$ & 0.89 \\
\hline Bahiagrass & $8-11$ & 68 & 33 & $50-54$ & 0.97 \\
\hline Tifton-85 & 15 & 77 & 33 & 66 & 1.32 \\
\hline Perennial peanut & $14-18$ & 42 & 32 & 60 & 1.1 \\
\hline Ryegrass & $18-22$ & 50 & 22 & 60 & 1.2 \\
\hline Oat & $14-18$ & 42 & 22 & 65 & 1.3 \\
\hline Clovers & $18-25$ & 27 & 18 & 75 & 1.5 \\
\hline
\end{tabular}


Table 3. Planting guide for forages.

\begin{tabular}{|c|c|c|c|c|}
\hline Crop & $\begin{array}{l}\text { Planting Rate } \\
\text { (Ib/A) }\end{array}$ & $\begin{array}{l}\text { Planting } \\
\text { Material }\end{array}$ & Planting Date** & $\begin{array}{l}\text { Months } \\
\text { from Planting to } \\
\text { Grazing }\end{array}$ \\
\hline \multicolumn{5}{|c|}{ Grasses } \\
\hline Bahiagrass & $25-30$ & Seed & $\begin{array}{l}\text { March (irrigated); June to August } \\
\text { (rainfed) }\end{array}$ & $3-12$ \\
\hline $\begin{array}{l}\text { Seeded (Common) } \\
\text { bermudagrass }\end{array}$ & $\begin{array}{c}10-15 \\
20 \text { (if coated) }\end{array}$ & Seed & $\begin{array}{l}\text { March (irrigated); June to August } \\
\text { (rainfed) }\end{array}$ & $?$ \\
\hline Bermudagrass & 1,200 & $\begin{array}{l}\text { Sprigs or green } \\
\text { tops }\end{array}$ & January 15-August 15 & $3-12$ \\
\hline Stargrass & $1,000-1,500$ & $\begin{array}{l}\text { Sprigs or green } \\
\text { tops }\end{array}$ & June 1-August 15 & $3-12$ \\
\hline Ryegrass & $20-30$ & Seed & October 1-November 15 & $1-2$ \\
\hline Pearl millet & $\begin{array}{l}12-15 \text { (in rows) } \\
20-40 \text { (broadcast) }\end{array}$ & Seed & March 15-June 30 & $1-2$ \\
\hline \multicolumn{5}{|c|}{ Small Grains } \\
\hline Rye & $90-120$ & Seed & October 15-November 15 & $1-2$ \\
\hline Oats & $\begin{array}{l}100-120 \text { (forage) } \\
60-80 \text { (grain) }\end{array}$ & Seed & $\begin{array}{l}\text { October 15-November } 1 \text { (grazing) } \\
\text { November 15-December } 15 \text { (grain) }\end{array}$ & $1-2$ \\
\hline Triticale & $90-120$ & Seed & November 15-December 20 (grain) & $1-2$ \\
\hline \multicolumn{5}{|c|}{ Legumes } \\
\hline Rhizoma peanut & $\begin{array}{c}900-1,200 \\
(80-100 \text { bu/acre })\end{array}$ & Rhizomes & December-March 15 & $8-15$ \\
\hline Alfalfa & $15-20$ & Seed & October 1-November 15 & $4-7$ \\
\hline Alyce clover & $15-20$ & Seed & April 15-June 30 & 2 \\
\hline Crimson clover & $20-25^{*}$ & Seed & October 1-November 15 & $2-3$ \\
\hline Red clover & $10-15^{*}$ & Seed & October 1-November 15 & $3-4$ \\
\hline Arrowleaf clover & $8-12$ & Seed & October 1-November 15 & $3-4$ \\
\hline White clover & $5-6^{*}$ & Seed & October 15-November 15 & $4-5$ \\
\hline \multicolumn{5}{|c|}{$\begin{array}{l}\text { *Assumes broadcast planting on bahiagrass or other perennial grass sod. Solid stands drilled into a prepared seedbed can be seeded at lower } \\
\text { rates. Seeding rates would be reduced approximately } 20 \% \text { for each component if a mixture were used. } \\
\text { **For fall-planted, cool-season annuals, producers in north Florida may begin planting in the early part of the planting date range. Producers ir } \\
\text { south Florida should wait and plant in the latter half to third of the planting date range. }\end{array}$} \\
\hline
\end{tabular}

